\title{
Somatic Embryogenesis in Cassava Genotypes from the Northeast of Brazil
}

\author{
Terezinha Feitosa ${ }^{1}$, João Luíz Pinheiro Bastos ${ }^{2}$, Luíz Ferreira Aguiar Ponte ${ }^{2}$, Thiago \\ Lustosa Jucá and Francisco de Assis de Paiva Campos ${ }^{2} *$ \\ ${ }^{1}$ Embrapa Agroindústria Tropica; C. P. 3761; Fortaleza - CE - Brasil. ${ }^{2}$ Universidade Federal do Ceará; \\ Departamento de Bioquímica e Biologia Molecular; C. P. 6039; bioplant@ufc.br; 60455-900; Fortaleza - CE - \\ Brasil
}

\begin{abstract}
A method for the induction of somatic embryogenesis in eight cassava genotypes from northeastern Brazil is described. The explants used were shoot apexes isolated both from in vitro grown plants and from shoots that sprouted from stem cuttings. Somatic embryogenesis was achieved in high frequencies by the addition in the induction medium of the auxin picloram over a wide range of concentrations. Green cotyledons of primary somatic embryos were used as explants to induce somatic (cyclic) secondary embryogenesis in an inducing medium supplemented with picloram at $12 \mathrm{mg} / \mathrm{L}$. The method could be used not only for the mass production of plants of the cassava genotypes, but also to generate explants (green cotyledons of somatic embryos) as themselves excellent targets for genetic transformation.
\end{abstract}

Key words: Manihot esculenta, cassava, somatic embryogenesis, plant tissue culture, picloram

\section{INTRODUCTION}

Cassava (Manihot esculenta) is increasing its importance in the economy of most of the Brazilian northeastern states. Besides its traditional use as food and fodder, cassava demand from the poultry and bakery industries is increasing. The need to increase production to match this increase in demand, have highlighted the need for more productive genotypes, adapted to the prevailing agro-ecological settings in the northeastern states. This demand is being met, at least in part, by the National Center for Research on Cassava and Fruit Crops (EMBRAPA Cassava and Fruit Crops) at Cruz das Almas, Bahia (Fukuda, 2003).
The new technologies for gene transfer are opening up new possibilities to generate improved cassava genotypes by integrating desired traits into farmer preferred cultivars; the ability to transfer new genetic materials into the cassava genome is essential if the crop is to fully benefit from major advances in plant biology (Kawano, 2003). Siritunga et al. (2004) provided the first demonstration that gene transfer techniques can be used to develop cassava varieties with useful agronomic traits. They obtained a transgenic cassava variety that expressed in roots and leaves high levels of the enzyme hydroxynitrile lyase (HNL). Elevated HNL in the transgenic plants were correlated with substantially reduced acetone cyanohydrin levels and increased cyanide volatilization in processed or homogenized roots.

\footnotetext{
${ }^{*}$ Author for correspondence
} 
Unlike acyanogenic cassava (Siritunga and Sayre, 2003), transgenic plants over expressing HNL in roots retain the herbivore deterrence of cyanogens while providing a safer food product.

As for all crop species, the development of transgenic cassava varieties would be reliant on the development of tissue culture systems capable of generating totipotent cells and tissues that in turn could act as the target for transgene insertion (Raemakers et al., 1997). Until recently, tissue culture techniques such as somatic embryogenesis (SE) and organogenesis for the cassava genotypes presently used in the Northeast of Brazil have not been developed. Here, we provide a detailed protocol for the induction of SE in eight cassava genotypes cultivated in northeastern states of Brazil.

\section{MATERIAL AND METHODS}

The cassava varieties used in this study (Água Morna, Amansa Burro, Aparecida, Mata Fome, Milagrosa, Rosa, Rosinha and Sacai) were obtained from the cassava germplasm bank maintained at the Agronomy School, Federal University of Ceará, Fortaleza, Brazil. For the establishment of in vitro cultures of all varieties used, fresh stem cuttings of $20-30 \mathrm{~cm}$ with $5-8$ nodes were obtained from mature plants. The cuttings were planted in plastic trays $(50 \times 30 \times 8$ $\mathrm{cm}$ ), filled with vermiculite and watered with halfstrength Murashige and Skoog (MS) salts (Murashige and Skoog, 1962) and kept under greenhouse conditions. When the newly sprouted stems reached $2 \mathrm{~cm}$, they were cut from the mother plant, taken to the lab and sterilized by immersion in a $1.5 \%$ sodium hypochlorite, $0.01 \%$ Triton X-100 solution for 5 minutes. Shoot tips containing up to three leaf primordial were aseptically dissected and transferred to test tubes $(15 \times 2.5 \mathrm{~cm})$ containing $10 \mathrm{ml}$ of solidified MS medium, supplemented with benzyladenine (BA), $0.1 \mathrm{mgL}-1$. The tubes containing the explants were incubated at $26 \pm 2{ }^{\circ} \mathrm{C}$ in a growth cabinet programmed to provide a light and dark cycle of $16 / 8$ hours provided by white fluorescent lamps $(25,3 \mu \mathrm{mol} \mathrm{m}-2 \mathrm{~s}-1)$. The cultures were maintained by monthly subculture of nodal explants in the same medium.

For the induction of somatic embryogenesis (SE), the explants used were shoot apexes containing up to three leaf primordia isolated from in vitro grown plants, as well as shoots that sprouted from stem cuttings. The explants were transferred under aseptic conditions to Petri dishes containing $25 \mathrm{ml}$ of solidified MS medium supplemented with $2 \%$ sucrose, $0.5 \mathrm{mgL}-1$ copper sulphate and picloram at $1,3,6,912$ or $15 \mathrm{mgL}-1$ and solidified with $0.6 \%$ agar. After three weeks of incubation under dark conditions at $26 \pm 2{ }^{\circ} \mathrm{C}$, the cultures were scored for the presence of somatic embryos. The method described by Zhang et al. (2001) was used for the maturation of the somatic embryos. Clusters of approximately 10 embryos were transferred to Petri dishes containing $25 \mathrm{ml}$ de maturation medium that consisted of MS salts and vitamins, $2 \%$ sucrose, $0,5 \mathrm{mgL}-1$ copper sulphate and $0.1 \mathrm{mgL}-1 \mathrm{BA}, \mathrm{pH} 5.8$ and solidified with $0.6 \%$ agar, and incubated for three to four weeks at $26 \pm 2^{\circ} \mathrm{C}$ under a $16 \mathrm{~h}$ photoperiod.

Green cotyledons from 2-3 week-old mature somatic embryos were used as source of explants for inducing secondary (cyclic) somatic embryogenesis. The cotyledons were divided into $4 \mathrm{~mm} 2$ pieces and transferred to Petri dishes containing $25 \mathrm{ml}$ of solidified MS medium supplemented with $2 \%$ sucrose, $0.5 \mathrm{mgL}-1$ copper sulphate and picloram at $1,3,6,912$ or $15 \mathrm{mgL}-1$ and solidified with $0.6 \%$ agar. After three weeks of incubation under dark conditions at $28 \pm 2{ }^{\circ} \mathrm{C}$, the cultures were scored for the presence of somatic embryos.

The experiments were carried out using the completely randomized design. Each treatment was repeated three times (30 explants per repetition) in a total of 90 explants per treatment and data recorded three weeks after the beginning of the treatments. The data were analyzed by the analysis of variance (ANOVA) using the SAS program (System for Windows, version 8.00) (SAS, 1999). The averages were compared through the significant minimum difference (smd), using the test of Tuckey at the level of $5 \%$.

\section{RESULTS AND DISCUSSION}

Shoot apexes isolated from in vitro grown plants of the cassava genotypes Água Morna and Rosinha were used to determine the effect of the concentration of the auxin picloram in the induction of SE. Within ten days of incubation of the explants in the induction medium, somatic embryos at the globular stage could be seen and between 14 and 21 days of incubation somatic 
embryos at more advanced stages (torpedo and cotyledon) could be seen (Fig. 1). The results presented in Table 1 indicated that in all of the concentrations tested, in both genotypes, picloram was able to induce SE at high frequencies as well as with a high number of somatic embryos per explant. For the genotype Água Morna, the frequency of SE induction at the picloram concentration of $1 \mathrm{mgL}-1$ was significantly lower than in the treatments were the picloram concentration was 12 or $15 \mathrm{mgL}-1$, but among the other treatments, no statistically significant differences were observed. For the genotype Rosinha, the frequency of SE induction for the treatments were the picloram concentration of 1 and $3 \mathrm{mgL}-1$ was statistically different from the treatment at $12 \mathrm{mgL}-1$ and among the other treatments no statistically significant differences were observed in the frequency of SE induction. Wherever possible, the use of in vitro grown plants as source of explants for the induction of somatic embryogenesis should be avoided, because as these plants pass through successive cycles of in vitro manipulations, and carry mutations, which might have been induced by the increase in the activity of transposons under in vitro conditions (Chakrabarty et al., 2003; Fehér et al., 2003). The additional in vitro cycles required for achieving SE or organogenesis from the explants, increases even further the likelihood of somaclonal variation. For this reason, a study was made whether shoot apexes isolated from shoots sprouted from stem cuttings were a suitable source of explants for inducing SE in several cassava genotypes. Picloram (4 mg.L-1) was added to the inducing medium because high levels of auxin in SE induction medium were associated with embryo mal-formation (Kantharajah and Golegaonkar, 2004). As shown in Table 2, SE was induced in all tested genotypes, even though it was possible to detect a genotype-specific response both in terms of the frequency of SE as well as in the number of somatic embryos per explant. It was interesting to observe that for genotypes Rosinha and Agua Morna both the frequency of SE and the mean number of somatic embryos per explants were similar no matter whether the explants were derived from in vitro grown plants or from shoots sprouted from stem cuttings (Tables 1 and 2).

In addition to provide explants isolated from plants not subjected to previous in vitro manipulation, the use of explants isolated from shoots sprouted from stem cutting had the additional advantage that it obviated the need to establish in vitro cultures of the desired genotypes in order to have a steady supply of explants for inducing SE. This would save the time needed to establish in vitro culture of most cassava genotypes, around three to four months (Oliveira et al., 2000).

The possibility of inducing secondary embryogenesis from cassava primary somatic embryos was examinated using green cotyledons from mature primary somatic embryos as explants. Embryo maturation was achieved by cultivating clusters of developing somatic embryos in maturation medium, as described by Zhang et al. (2001). The results presented in Table 3 and Fig. 1 showed the results of cultivating small pieces of green cotyledons of somatic embryos in culture medium containing increasing amounts of picloram. In all of the picloram concentrations tested secondary embryogenesis was induced in both genotypes. As observed in the experiment for the induction of primary SE (Table 1), although both genotypes were highly embryogenic, Água Morna gave a better response than Rosinha both in terms of frequency of secondary somatic embryogenesis and in the number of somatic embryos per explant. It was also interesting to observe that the concentration of picloram did not significantly affect the frequency of embryogenesis and the number of embryos per explant. A comparison between the data presented in Tables 1 and 3 reveals that taking into account the number of somatic embryos obtained per explant, the induction of somatic embryogenesis either from isolated shoot apexes or from pieces of green cotyledons of mature somatic embryos did not differ significantly. However, as from each green cotyledon at least four explants could be obtained for inducing SE, these explants were better suited for obtaining great numbers of somatic embryos than isolated shoot apexes. This was very convenient, especially when a high number of somatic embryos were desired. Green cotyledons of somatic embryos should also be excellent targets for genetic transformation experiments, not only because they were highly embryogenic but also due to the high number of somatic embryos that could be produced per explant. 


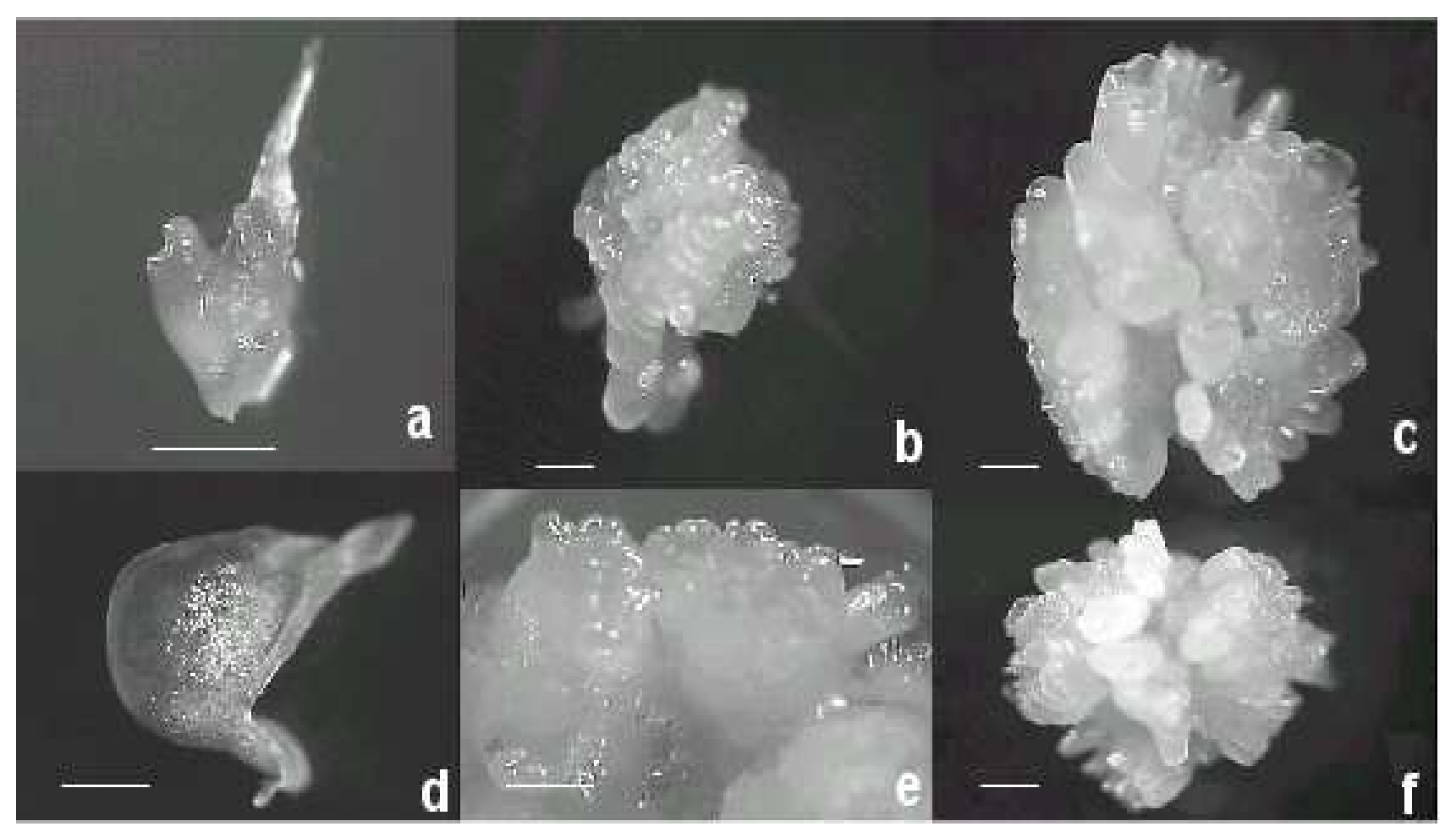

Figure 1 - Primary and secondary somatic embryogenesis in cassava (Manihot esculenta) cv. Rosinha. (a) Shoot apex in induction medium; (b) primary somatic embryos at the globular stage on the explant surface after ten days of culture in induction medium; (c) torpedo and cotyledonar stages somatic embryos on the explant surface after 21 days of culture in induction medium; (d) Green cotyledon of primary somatic embryo; (e) induction of secondary (cyclic) embryogenesis after ten days of incubation of somatic cotyledons in induction medium; (f) torpedo and cotyledon stages secondary somatic embryos on the surface of the explant after 21-days of incubation in induction medium

Table 1 - Effect of picloram concentration on somatic embryogenesis induction from isolated shoot apexes of in vitro grown cassava (Manihot esculenta Crantz) cvs. Água Morna and Rosinha. The values given for the number of embryos/per explant represent the sum of the number of embryos in the globular, heart, torpedo and cotyledon stages. The evaluation was performed after 3 weeks culture on MS medium supplemented with different concentrations of picloram. In the columns and rows, numbers followed by different letters (lower case, columns; upper case, rows) are statistically different (Tuckey 5\%).

\begin{tabular}{ccccc}
$\begin{array}{c}\text { Picloram } \\
\left(\mathbf{m g L}^{-1}\right)\end{array}$ & \multicolumn{2}{c}{ Água Morna } & \multicolumn{2}{c}{ Rosinha } \\
\hline & $\begin{array}{c}\text { Frequency of somatic } \\
\text { embryogenesis }(\%)\end{array}$ & $\begin{array}{c}\text { Number of embryos } \\
\text { per explant }\end{array}$ & $\begin{array}{c}\text { Frequency of somatic } \\
\text { embryogenesis }(\%)\end{array}$ & $\begin{array}{c}\text { Number of embryos } \\
\text { per explant }\end{array}$ \\
\hline 1 & $14,4 \pm 3,8^{\mathrm{bB}}$ & $7,0 \pm 1,8^{\mathrm{b}}$ & $27,7 \pm 10,1^{\mathrm{dA}}$ & $8,5 \pm 4,5^{\mathrm{b}}$ \\
3 & $36,6 \pm 15,2^{\mathrm{abB}}$ & $14,7 \pm 8,4^{\mathrm{ab}}$ & $48,8 \pm 9,6^{\mathrm{cA}}$ & $25,6 \pm 6,5^{\mathrm{a}}$ \\
6 & $44,4 \pm 10,7^{\mathrm{abB}}$ & $16,2 \pm 4,7^{\mathrm{ab}}$ & $72,1 \pm 7,6^{\mathrm{abA}}$ & $34,3 \pm 3,7^{\mathrm{a}}$ \\
9 & $37,2 \pm 12,0^{\mathrm{abB}}$ & $18,1 \pm 2,6^{\mathrm{ab}}$ & $61,1 \pm 10,1^{\mathrm{bcA}}$ & $36,5 \pm 6,1^{\mathrm{a}}$ \\
12 & $55,5 \pm 18,9^{\mathrm{aB}}$ & $18,9 \pm 3,2^{\mathrm{ab}}$ & $80,0 \pm 5,7^{\mathrm{aA}}$ & $24,4 \pm 7,6^{\mathrm{a}}$ \\
15 & $54,4 \pm 33,3^{\mathrm{aB}}$ & $25,0 \pm 1,2^{\mathrm{a}}$ & $76,6 \pm 8,7^{\mathrm{abA}}$ & $27,7 \pm 5,5^{\mathrm{a}}$ \\
\hline C.V $(\%)$ & 29,9 & 21,9 & 10,7 & 21,6 \\
\hline
\end{tabular}


Table 2 - Induction of secondary embryogenesis from shoot apexes isolated from shoots sprouted from stem cuttings, in eight varieties of cassava (Manihot esculenta Crantz). The explants were cultivated in in MS medium supplemented with $4 \mathrm{mg} / \mathrm{L}$ picloram. The values given for the number of embryos/per explant represent the sum of the number of embryos in the globular, heart, torpedo and cotyledon stages. The evaluation was performed after 3 weeks culture. In the columns, numbers followed by different letters are statistically different (Tuckey 5\%).

\begin{tabular}{lll}
\hline \multicolumn{1}{c}{ Cultivar } & $\begin{array}{l}\text { Frequency Number of of } \\
\text { somatic embryos/explant }\end{array}$ & embryogenesis (\%) \\
\hline Água morna & $31,0 \pm 8,5^{\mathrm{b}}$ & $4,0 \pm 1,0^{\mathrm{a}}$ \\
Amansa Burro & $48,7 \pm 10,1^{\mathrm{ab}}$ & $3,1 \pm 0,9^{\mathrm{a}}$ \\
Aparecida & $67,9 \pm 10,5^{\mathrm{ab}}$ & $1,6 \pm 0,5^{\mathrm{a}}$ \\
Mata Fome & $76,9 \pm 0,8^{\mathrm{a}}$ & $4,1 \pm 2,1^{\mathrm{a}}$ \\
Milagrosa & $56,8 \pm 33,5^{\mathrm{ab}}$ & $10,6 \pm 10,0^{\mathrm{a}}$ \\
Rosa & $82,9 \pm 7,8^{\mathrm{a}}$ & $7,5 \pm 0,5^{\mathrm{a}}$ \\
Rosinha & $41,0 \pm 7,6^{\mathrm{ab}}$ & $8,0 \pm 2,0^{\mathrm{a}}$ \\
Sacaí & $48,5 \pm 18,7^{\mathrm{ab}}$ & $4,6 \pm 0,9^{\mathrm{a}}$ \\
\hline C.V. $(\%)$ & 21,5 & 20,0 \\
\hline
\end{tabular}

Table 3 - Effect of picloram concentration on secondary somatic embryogenesis induction from green cotyledons of somatic embryos of cassava (Manihot esculenta Crantz) cvs. Água Morna and Rosinha. The values given for the number of embryos/per explant represent the sum of the number of embryos in the globular, heart, torpedo and cotyledon stages. The evaluation was performed after 3 weeks culture on MS medium supplemented with different concentrations of picloram. In the columns and rows, numbers followed by different letters (lower case, columns; upper case, rows) are statistically different (Tuckey 5\%).

\begin{tabular}{ccccc}
\hline $\begin{array}{c}\text { Picloram } \\
(\mathbf{m g} / \mathbf{L})\end{array}$ & \multicolumn{2}{c}{ Água Morna } & Rosinha \\
\hline & $\begin{array}{c}\text { Frequency of somatic } \\
\text { embryogenesis }(\%)\end{array}$ & $\begin{array}{c}\text { Number of } \\
\text { embryos/explant }\end{array}$ & $\begin{array}{c}\text { Frequency of somatic } \\
\text { embryogenesis }(\%)\end{array}$ & $\begin{array}{c}\text { Number of } \\
\text { embryos/explant }\end{array}$ \\
\hline 1 & $34,4 \pm 37,8^{\mathrm{aA}}$ & $4,9 \pm 3,7^{\mathrm{aA}}$ & $55,5 \pm 13,8^{\mathrm{aA}}$ & $28,8 \pm 35,1^{\mathrm{aA}}$ \\
3 & $37,7 \pm 10,1^{\mathrm{aA}}$ & $6,3 \pm 0,6^{\mathrm{aA}}$ & $43,3 \pm 20,2^{\mathrm{aA}}$ & $12,5 \pm 5,2^{\mathrm{aA}}$ \\
6 & $38,8 \pm 1,9^{\mathrm{aA}}$ & $9,6 \pm 1,3^{\mathrm{aA}}$ & $55,5 \pm 23,4^{\mathrm{aA}}$ & $16,7 \pm 4,8^{\mathrm{aA}}$ \\
9 & $48,8 \pm 1,9^{\mathrm{aA}}$ & $10,7 \pm 5,6^{\mathrm{aA}}$ & $54,4 \pm 18,9^{\mathrm{aA}}$ & $28,5 \pm 17,4^{\mathrm{aA}}$ \\
12 & $59,9 \pm 12,0^{\mathrm{aA}}$ & $16,7 \pm 9,9^{\mathrm{aA}}$ & $58,8 \pm 15,7^{\mathrm{aA}}$ & $34,9 \pm 8,5^{\mathrm{aA}}$ \\
15 & $73,3 \pm 20,2^{\mathrm{aA}}$ & $16,3 \pm 4,9^{\mathrm{aA}}$ & $46,6 \pm 23,3^{\mathrm{aA}}$ & $37,0 \pm 8,4^{\mathrm{aA}}$ \\
\hline C.V $(\%)$ & 40,10 & 6,77 & 51,33 & 50 \\
\hline
\end{tabular}

\section{RESUMO}

Um método para a indução de embriogênese somática em oito genótipos de mandioca cultivados no Nordeste brasileiro foi desenvolvido. A indução de embriogênese somática foi feita utilizando como explantes ápices caulinares isolados de plantas cultivadas in vitro e ápices caulinares isolados a partir de brotações induzidas em casa-de-vegetação em manivas de plantas adultas. Em todos os genótipos a auxina picloram, em uma ampla faixa de concentrações, foi capaz de induzir embriogênese somática em altas freqüências e com um grande número de embriões por explante. Foi mostrado também, que é possível induzir embriogênese somática secundária (cíclica) a partir de cotilédones verdes de embriões somáticos maduros, utilizando picloram no meio de indução. O método aqui apresentado poderá ser utilizado para a produção em massa de plantas dos genótipos utilizados. A alta frequiência de embriogênese somática secundária obtida quando cotilédones verdes de embriões somáticos são utilizados como explantes, mostra que tais cotilédones podem se constituir em excelentes alvos para a transformação genética e posterior obtenção de plantas transgênicas de mandioca. 


\section{REFERENCES}

Chakrabarty, D.; Yu, K.W. and Paek, K.Y. (2003), Detection of DNA methylation changes during somatic embryogenesis of Siberian ginseng (Eleuterococcus senticosus). Plant Science, 165, 6168.

Fehér, A.; Pasternak, T.P. and Dudits, D. (2003), Transition of somatic cells to an embryogenic state. Plant Cell, Tissue and Organ Culture, 74, 201-228.

Fukuda, C. (2003), Mandioca, raiz de respeito. Agroanalysis, 22 (10), 43-46.

Kantharajah, A.S. and Golegaonkar, P.G. (2004), Somatic embryogenesis in eggplant. Scientiae Horticulturae, 99, 107-117.

Kawano, K. (2003), Thirty years of cassava breeding for productivity - biological and social factors for success. Crop Science, 43, 1325-1335.

Murashige, T. and Skoog, F. (1962), A revised mediun for rapid growth and bio-assays with tobacco tissue cultures. Physiologia Plantarum, 1, 437-496.
Oliveira, P. O.; Gomes, T. S. and Vilarinhos, A.D. 2000), Avaliação de um sistema de micropropagação massal de variedades de mandioca. Pesquisa Agropecuária Brasileira, 35, (12), 2329-2334.

Raemakers, C.J.J.M.; Sofiari, E., Taylor, N.J., Henshaw, G.G.; Jacobsen, E. and Visser, R.G.F. (1997), Regeneration and transformation in cassava. Euphytica, 96, 153-161.

SAS (1999), Sas Institute Inc., Cary, NC.

Siritunga, D.; Arias-Garzon, D.; White, W. and Sayre, R.T. (2004), Over-expression of hydroxynitrile lyase in transgenic cassava roots accelerates cyanogenesis and food detoxification. Plant Biotechnology Journal, 2, 37-43.

Siritunga, D. and Sayre, R.T. (2003), Generation of cyanogen-free transgenic cassava. Planta, 217, 367373.

Zhang, P.; Phansiri, S. and Puonti-Kaerlas, J. (2001), Improvement of cassava organogenesis by the use of silver nitrate in vitro. Plant Cell, Tissue and Organ Culture, 67, 47-54. 